\title{
Expression and role of EGFR ligands induced in airway cells by PM2.5 and its components
}

\author{
M. Rumelhard, K. Ramgolam, R. Hamel, F. Marano and A. Baeza-Squiban
}

ABSTRACT: The aim of the current study was to establish the epidermal growth factor receptor (EGFR) ligand expression profile in human airway epithelial cells exposed to either particulate matter (PM) with an aerodynamic diameter $<2.5 \mu \mathrm{m}$ (PM2.5) or its components and the involvement of EGFR ligands in PM2.5-provoked airway inflammation.

EGFR ligand mRNA and protein expression were studied in a human bronchial epithelial cell line and normal nasal cells exposed to noncytotoxic concentrations of PM2.5 or its components. The autocrine role of EGFR ligands in airway epithelial cell pro-inflammation was determined by adding conditioned media from PM2.5-treated cells to fresh cells and measuring the secretion of granulocyte-macrophage colony-stimulating factor (GM-CSF), a pro-inflammatory biomarker.

PM2.5 increased amphiregulin, transforming growth factor- $\alpha$ and heparin-binding EGF-like growth factor mRNA expression and protein secretion, with a slight contribution of aqueous metallic compounds and a strong participation of organic components putatively attributed to PM polyaromatic hydrocarbon content. PM2.5-induced EGFR ligands were involved in cellular GMCSF release.

The current study revealed upregulation of several epidermal growth factor receptor ligands by airway epithelial cells exposed to particulate matter with an aerodynamic diameter $<\mathbf{2 . 5} \boldsymbol{\mu m}$ and their contribution to bronchial epithelial cell granulocyte-macrophage colony-stimulating factor secretion by an autocrine action, suggesting that these ligands could elicit and sustain the particulate matter-induced airway pro-inflammatory response and contribute to bronchial remodelling.

KEYWORDS: Ambient particles, epidermal growth factor receptor ligands, inflammation, organic particulate matter with a diameter $<2.5 \mu \mathrm{m}$, respiratory epithelial cells

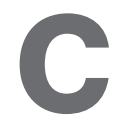
onsiderable attention has been devoted to the health effects of atmospheric pollution, particularly in urban areas. Numerous epidemiological studies have correlated exposure to fine particulate matter (PM) with cardiovascular and respiratory morbidity and mortality, including the development of chronic bronchitis, asthma and lung cancer [1]. Urban PM with a diameter $<2.5 \mu \mathrm{m}$ (PM2.5) is a complex mixture, including soot, produced by combustion with which organic, metallic and biological components are associated.

Human and animal studies have shown lung inflammation following brief exposure to diesel exhaust particles or to concentrated ambient particles $[2,3]$. In addition, the in vitro release of pro-inflammatory cytokines, i.e. granulocytemacrophage colony-stimulating factor (GM-CSF), interleukin (IL)-8, etc. by bronchial epithelial cells exposed to PM2.5, has shown the role of epithelium in this airway pro-inflammatory response [4]. Long-term exposure to pollution has been associated with histopathological lung damage, such as bronchioli wall thickening, concomitant with the presence of numerous particles in the lungs of exposed individuals [5]. It is thus suspected that PM2.5 may provoke or exacerbate airway remodelling, a phenomenon characterised, especially in chronic obstructive pulmonary disease, by epithelial mucous metaplasia associated with airway wall fibrosis, inflammation, enlargement of bronchial smooth muscle mass and modifications of lung growth factor expression and/or functions

\section{AFFILIATIONS}

Laboratory of Cytophysiology and Cellular Toxicology, University of Paris Diderot, Paris, France.

\section{CORRESPONDENCE}

M. Rumelhard

Laboratory of Cytophysiology and Cellular Toxicology

Tour 53-54

Case Courrier 7073

University of Paris Diderot-Paris 7

2 place Jussieu

75251 Paris Cedex 05

France

Fax: 33144276999

E-mail: melina.rumelhard@univ-

diderot-paris.fr

Received:

July 102007

Accepted after revision:

August 172007

SUPPORT STATEMENT

This study was supported by CAMPLP (Caisse d'Assurance Maladie des Professions Libérales de Province, Paris, France).

STATEMENT OF INTEREST

A statement of interest for this study can be found at

www.erj.ersjournals.com/misc/ statements.shtml 
(such as epidermal growth factor (EGF) and basal fibroblast growth factor, etc.) [6]. Furthermore, as recently shown in the current authors' laboratory, exposure of human bronchial epithelial cells to PM2.5 or diesel exhaust particles leads to the release of amphiregulin, a ligand of the EGF receptor (EGFR) [7].

EGFR is a $173 \mathrm{kD}$ receptor tyrosine kinase predominantly located at the basolateral surface of polarised epithelial cells. Several ligands are able to bind to the mammalian EGFR (cerbB1, human epidermal receptor 1) with various affinities: EGF, transforming growth factor (TGF)- $\alpha$, heparin-binding EGF-like growth factor (HB-EGF), amphiregulin, betacellulin, epiregulin and epigen. EGFR ligands have autocrine properties, which may explain the preferential co-localisation of the ligands and their receptor at the basolateral surface. Indeed, TGF- $\alpha$ and amphiregulin are functionally involved in an EGFR autocrine growth loop in human normal bronchial epithelial cells [8].

EGFR and its ligands play a pivotal role in repair and maintenance of epithelial tissues [9]. Indeed, it has been shown that EGF and EGFR are involved in repair of scrape-wounded human bronchial epithelial (16HBE)14o- monolayers in vitro [10]. Moreover, EGFR is overexpressed in the airway epithelium of asthmatic subjects [10]. In addition to this implication in tissue repair, amphiregulin and HB-EGF have been associated with pro-inflammatory cytokine release (GM-CSF, IL-8) after exposure to PM or cigarette smoke, respectively [7, 11].

The aims of the current study were to establish the expression pattern of EGFR ligands induced in human respiratory epithelial cells by PM2.5 and its different components, and then to determine the resulting consequences, for airway epithelial cells, of increased EGFR ligand production, due to their potential involvement in pro-inflammatory responses.

\section{MATERIALS AND METHODS Particles}

PM2.5 was collected in Vitry-sur-Seine, a suburban city near Paris (France), according to a previously published method [12]

The polyaromatic hydrocarbon (PAH) and metal content of the PM was characterised, respectively, by high-pressure liquid chromatography after extraction with dichloromethane, and by inductively coupled plasma-atomic emission spectrometry or flame photometry (table 1) according to previously described methods [12].

Stock suspensions of native particles $\left(2 \mathrm{mg} \cdot \mathrm{mL}^{-1}\right)$ were prepared in a $0.04 \%$ dipalmitoyl phosphatidyl lecithine (DPL; Sigma-Aldrich, Saint-Quentin-Fallavier, France) solution. DPL is a surfactant component used to maintain particles in suspension, and is consequently used as a negative control for particle exposure. For treatment, PM was sonicated six times for $10 \mathrm{~s}$ (Vibracell; Bioblock Scientific, Illkrich, France) and suspended in culture medium.

The organic extract was obtained by extraction of PM2.5 with dichloromethane in an accelerated solvent extractor (ASE 200; Dionex, Sunnyvale, CA, USA). The extract was dried and dissolved in dimethyl sulfoxide.

The aqueous extract containing hydrosoluble components was obtained after two 10 -min centrifugations of the $2 \mathrm{mg} \cdot \mathrm{mL}^{-1}$

\begin{tabular}{|c|c|c|}
\hline \multirow{2}{*}{$\begin{array}{l}\text { TABLE } 1 \\
\text { PAH } \mu g \cdot g^{-1}\end{array}$} & \multicolumn{2}{|c|}{$\begin{array}{l}\text { Polyaromatic hydrocarbon (PAH) and metal } \\
\text { content in particulate matter with a diameter } \\
<2.5 \mu \mathrm{m}\end{array}$} \\
\hline & & \\
\hline \multicolumn{2}{|l|}{ Naphtalene } & 8.12 \\
\hline \multicolumn{2}{|c|}{ Acenaphtalene } & n.d. \\
\hline \multicolumn{2}{|c|}{ Fluorene } & 0.41 \\
\hline \multicolumn{2}{|c|}{ Phenanthrene } & 2.51 \\
\hline \multicolumn{2}{|c|}{ Anthracene } & 0.58 \\
\hline \multicolumn{2}{|c|}{ Fluoranthrene } & 4.84 \\
\hline \multicolumn{2}{|l|}{ Pyrene } & 5.48 \\
\hline \multicolumn{2}{|c|}{ Benzo(a)anthracene } & 2.88 \\
\hline \multicolumn{2}{|l|}{ Chrysene } & 5.67 \\
\hline \multicolumn{2}{|c|}{ Benzo(b)fluoranthrene } & 14.64 \\
\hline \multicolumn{2}{|c|}{ Benzo(k)fluoranthrene } & 5.44 \\
\hline \multicolumn{2}{|c|}{ Benzo(a)pyrene } & 5.29 \\
\hline \multicolumn{2}{|c|}{ Dibenzo(a,h)anthracene } & 11.88 \\
\hline \multicolumn{2}{|c|}{ Benzo(ghi)perylene } & 13.30 \\
\hline \multicolumn{2}{|c|}{ Indeno pyrene } & 7.31 \\
\hline \multicolumn{2}{|c|}{$2-3$ cycles } & 11.62 \\
\hline \multicolumn{2}{|l|}{$>3$ cycles } & 76.72 \\
\hline \multicolumn{2}{|l|}{ Total } & 88.34 \\
\hline \multicolumn{2}{|c|}{ Soluble organic fraction \% } & 9 \\
\hline \multicolumn{3}{|c|}{ Metals $\mathrm{mg} \cdot \mathrm{g}^{-1}$} \\
\hline \multicolumn{2}{|c|}{$\mathrm{Na}$} & 20.7 \\
\hline \multicolumn{2}{|l|}{$\mathrm{Mg}$} & 4.3 \\
\hline \multicolumn{2}{|l|}{$\mathrm{Al}$} & 10.4 \\
\hline \multicolumn{2}{|l|}{ K } & 8 \\
\hline \multicolumn{2}{|l|}{$\mathrm{Ca}$} & 59.6 \\
\hline $\mathrm{Fe}$ & & 13.5 \\
\hline $\mathrm{Zn}$ & & 1.3 \\
\hline $\mathrm{Ti}$ & & 0.8 \\
\hline $\mathrm{Mn}$ & & 0.42 \\
\hline $\mathrm{Cu}$ & & 0.37 \\
\hline $\mathrm{Sb}$ & & 0.093 \\
\hline $\mathrm{Pb}$ & & 0.52 \\
\hline V & & 0.11 \\
\hline $\mathrm{Cr}$ & & 0.077 \\
\hline $\mathrm{Ni}$ & & 0.059 \\
\hline As & & 0.025 \\
\hline $\mathrm{Cd}$ & & 0.012 \\
\hline Total & & 120.29 \\
\hline Fraction \% & & 12 \\
\hline
\end{tabular}

n.d.: not done

particle suspension, at $10,000 \times g$, followed by filtration of the supernatant through a $0.22 \mu \mathrm{m}$ filter (Millex® GV, Carrigtohill, Cork, Ireland). Soluble metals present in the particle aqueous extract were depleted by filtration on chelating ion-exchange resins with Chelex® resin according to the manufacturer's instructions (Chelex 100, Bio-Rad, Marnes-la-Coquette, France).

Particles collected after the two centrifugations and suspended in a solution of DPL at $2 \mathrm{mg} \cdot \mathrm{mL}^{-1}$ constituted the washed PM2.5 devoid of hydrosoluble components.

Black carbon particles at $2 \mathrm{mg} \cdot \mathrm{mL}^{-1}$ (95 nm diameter; Degussa, Frankfurt, Germany) were used to mimic the carbonaceous 


\begin{tabular}{|c|c|c|}
\hline \multirow[t]{2}{*}{ TABLE 2} & \multicolumn{2}{|c|}{$\begin{array}{l}\text { Forward and reverse primers of epidermal growth factor ligands and reduced glyceraldehyde phosphate } \\
\text { dehydrogenase (GAPDH) }\end{array}$} \\
\hline & Forward primer & Reverse primer \\
\hline Amphiregulin & 5'TGG TGC TGT CGC TCT TGA TA3' & 5'CCC TGA AGA CAT CTC АCT TC3' \\
\hline Betacellulin & 5'GAT GAA GGC TAC ATT GGA GC3' & 5'TTA CGA CGT TTC CGA AGA GG3' \\
\hline GAPDH & 5'TCA CCA GGG CTG CTT TTA AC3' & 5'GAC AAG CTT CCC GTT CTC AG3' \\
\hline TGF- $\alpha$ & 5'CCC TGG CTG TCC TTA TCA TC3' & 5'GTT TCT GAG TGG CAG CAA GC3' \\
\hline
\end{tabular}

core of PM2.5, as production of PM2.5-devoid of its organic compounds was technically impossible.

\section{Treatment}

Cells were exposed to noncytotoxic concentrations of native PM2.5 (1, 5 or $\left.10 \mu \mathrm{g} \cdot \mathrm{cm}^{-2}\right)$ or to a volume of washed PM2.5, aqueous extract and black carbon particles equivalent to the volume of native PM2.5. Organic extract was used at a concentration equivalent to that found on PM2.5, this value was calculated according to the proportion of soluble organic fraction in the total dry weight of PM2.5 (9\%).

For the conditioned media, the following protocol was followed: cells were exposed for $24 \mathrm{~h}$ to PM2.5 and the culture medium was removed, centrifuged for $10 \mathrm{~min}$ at $10,000 \mathrm{~g}$ to eliminate particles, and the GM-CSF content measured. This constituted the conditioned media, which was applied for $24 \mathrm{~h}$ to fresh cells to further investigate the secreted GM-CSF, amphiregulin and TGF- $\alpha$.

Anti-EGFR monoclonal antibody (clone LA1) was purchased from R\&D Systems (Abingdon, UK) and used at $0.5 \mu \mathrm{g} \cdot \mathrm{mL}^{-1}$. Anti-amphiregulin, anti-HB-EGF and anti-TGF- $\alpha$ polyclonal antibodies were also purchased from R\&D Systems and used at respective concentrations of 20,10 and $1 \mu \mathrm{g} \cdot \mathrm{mL}^{-1}$.

Monoclonal mouse immunoglobulin (Ig)G antibody used as a control antibody was purchased from DakoCytomation (Dako France, Trappes, France). $\alpha$-naphthoflavone (Sigma-Aldrich) was used as antagonist of the aryl hydrocarbon receptor (AhR). Benzo(a)pyrene (Sigma-Aldrich) at $1 \mu \mathrm{M}$ was used as a positive control for AhR activation.

\section{Cell cultures}

16HBE14o- cells were kindly provided by D.C. Gruenert (Research Facility, California Pacific Medical Center, San Francisco, CA, USA). Primary cultures of normal human nasal epithelial (NHNE) cells were obtained from turbinates of patients undergoing turbinectomy (kindly supplied by J. Soudant, Service ORL, CHU La Pitié-Salpétrière, Paris, France).

Cell culture details are provided in the online supplementary material. During treatment and for $4 \mathrm{~h}$ before cell exposure, $16 \mathrm{HBE}$ and NHNE cells were grown in DMEM/F12 without growth factors.

\section{Gene expression analysis}

Total RNA were extracted from 16HBE14o- cells using an SV Total RNA Isolation kit (Promega, Charbonnieres, France) according to the manufacturer's instructions. Reverse transcription (RT) of $1 \mu \mathrm{g}$ of total RNA was then performed as described by RUMELHARD et al. [13], one-tenth of the RT reaction was then amplified using quantitative PCR in the presence of 1X Brilliant ${ }_{\circledR}$ SYBR $_{\circledast}$ Green Master mix (Stratagene, La Jolla, CA, USA) and forward and reverse primers (table 2). Amphiregulin, betacellulin, HB-EGF and reduced glyceraldehyde phosphate dehydrogenase primers were purchased from Operon Biotechnologies (Cologne, Germany) and TGF- $\alpha$ primers from Invitrogen (Paisley, UK). Samples were amplified in a MX3000P ${ }_{\mathbb{B}}$ QPCR System (Stratagene) under the following conditions: $10 \mathrm{~min}$ at $94^{\circ} \mathrm{C} ; 40$ cycles of $30 \mathrm{~s}$ at $94^{\circ} \mathrm{C}$, $1 \mathrm{~min}$ at $58^{\circ} \mathrm{C}$ and $45 \mathrm{~s}$ at $72^{\circ} \mathrm{C} ; 1 \mathrm{~min}$ at $95^{\circ} \mathrm{C}$; and a ramp from $55^{\circ} \mathrm{C}$ to $95^{\circ} \mathrm{C}$.

The reduced glyceraldehyde phosphate dehydrogenase gene was used as an internal standard. The comparative cycle threshold method ( $2^{-\Delta \Delta C t}$ method) was used to analyse data and determine the relative abundance of the target genes. $\mathrm{Ct}$ is the threshold cycle at which $\mathrm{SYBR}_{\mathbb{R}}$ Green emission is determined to be statistically different above background. To obtain the $\Delta \Delta \mathrm{Ct}$ values, the difference between $\mathrm{Ct}$ of a target gene $(\mathrm{CtA})$ and house keeping gene $(\mathrm{CtB})$ was calculated in treated cells $(\Delta \mathrm{CtT}=\mathrm{CtA}, \mathrm{T}-\mathrm{CtB}, \mathrm{T})$ and in untreated cells $(\Delta \mathrm{CtUT}=\mathrm{CtA}, \mathrm{UT}-\mathrm{CtB}, \mathrm{UT})$. Finally, the relative abundance was calculated as $2^{-\Delta \Delta \mathrm{Ct}}$.

\section{Analysis of EGFR ligand and GM-CSF release}

Cell culture media was removed from cells and centrifuged for $10 \mathrm{~min}$ at $10,000 \times g\left(4^{\circ} \mathrm{C}\right)$. Enzyme-linked immunosorbent assay kits for amphiregulin, TGF- $\alpha$, betacellulin and GM-CSF (R\&D Systems) were then used following the manufacturer's instructions.

\section{Statistical analysis}

Results are expressed as mean \pm SD. Data comparisons were carried out using one way ANOVA followed by Dunnett's post-test to compare treatments with their controls, or by Student-Newman-Keuls to compare the different treatment groups. Differences were considered significant for $\mathrm{p}<0.05$.

\section{RESULTS}

\section{Effects of PM2.5 on EGFR ligand mRNA and protein expression in respiratory epithelial cells}

A time-course study $(2,6,18,24$ and $48 \mathrm{~h})$ with $16 \mathrm{HBE}$ cells treated with PM2.5 at $10 \mu \mathrm{g} \cdot \mathrm{cm}^{-2}$, a noncytotoxic concentration (data not shown), revealed that among the four EGFR ligands 

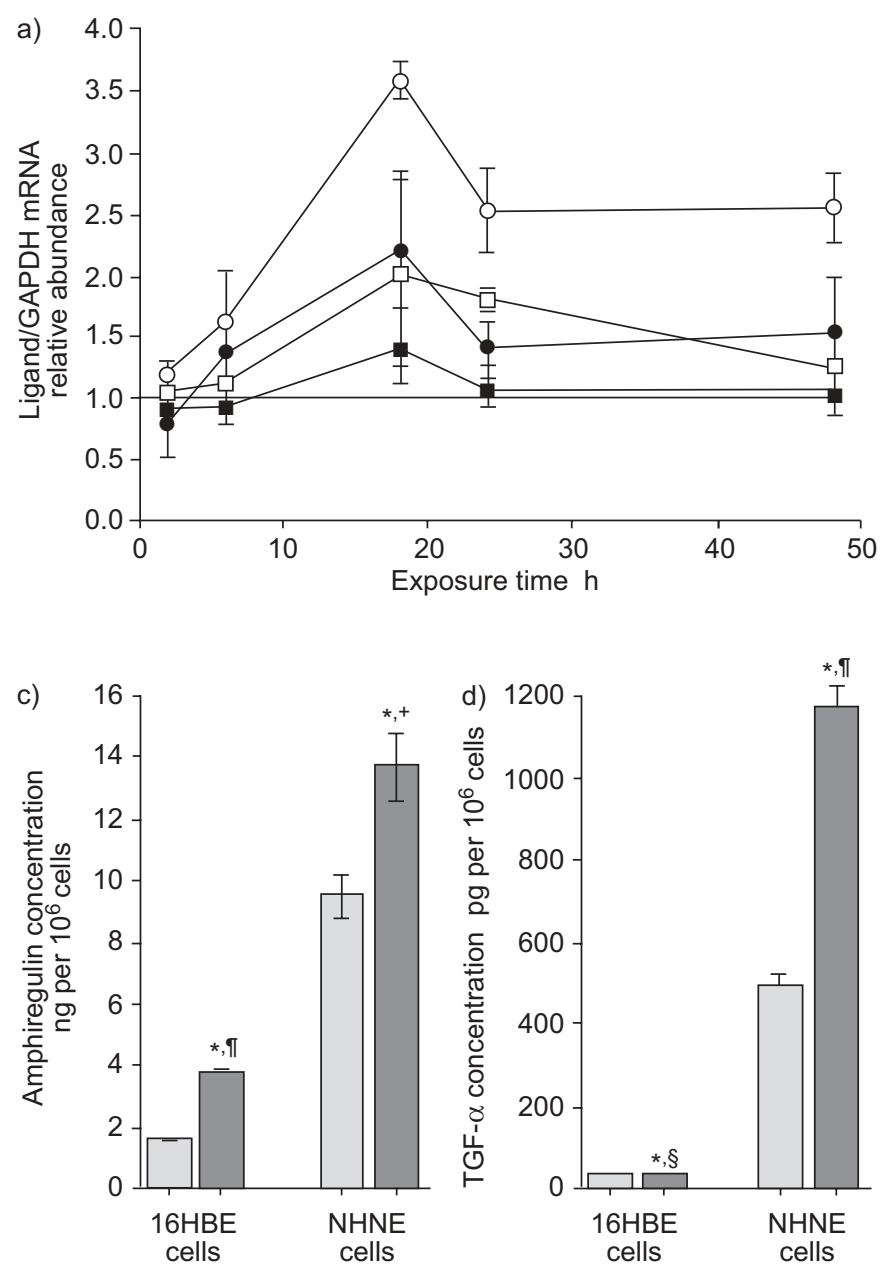

studied, the earliest upregulated genes were amphiregulin and HB-EGF from $6 \mathrm{~h}$ (fig. 1a). Amphiregulin and HB-EGF were further upregulated by 3.6- and 2.1-fold, respectively, up to $18 \mathrm{~h}$, this then diminished in the following $30 \mathrm{~h}$ but remained sustained for amphiregulin (2.5-fold at $48 \mathrm{~h}$ ). TGF- $\alpha$ mRNA expression was significantly increased to approximately the same extent (two-fold) as that of HB-EGF mRNA after 18-24 h of exposure, but was more transient as it descended to basal levels at $48 \mathrm{~h}$. Betacellulin mRNA expression in 16HBE cells was virtually unmodulated by PM2.5 exposure.

The time-course study $(2,6,18,24$ and $48 \mathrm{~h})$ shown in figure $1 \mathrm{~b}$ for $10 \mu \mathrm{g} \cdot \mathrm{cm}^{-2} \mathrm{PM} 2.5$ exposure revealed a significant induction of both amphiregulin and TGF- $\alpha$ secretion in 16HBE cell culture supernatants starting at $18 \mathrm{~h}$ of exposure. Amphiregulin secretion increased throughout the time, reaching a concentration of $7.4 \mathrm{ng} \cdot \mathrm{mL}^{-1}$ after $48 \mathrm{~h}$ of exposure, whereas TGF- $\alpha$ secretion did not evolve and even decreased $\left(24 \mathrm{pg} \cdot \mathrm{mL}^{-1}\right.$ at $18 \mathrm{~h}$ and $21 \mathrm{pg} \cdot \mathrm{mL}^{-1}$ at $24 \mathrm{~h}$ ). For constitutive and also inducible release, the amount of amphiregulin (in the $\mathrm{ng} \cdot \mathrm{mL}^{-1}$ range) was higher than that of TGF- $\alpha$ (in the $\mathrm{pg} \cdot \mathrm{mL}^{-1}$ range). The dose-dependent study (supplementary fig. 1) revealed a significant secretion of both ligands from $1 \mu \mathrm{g} \cdot \mathrm{cm}^{-2}$ of PM2.5 that seemed to be maximal from $5 \mu \mathrm{g} \cdot \mathrm{cm}^{-2}$ of PM2.5. No release of betacellulin was detectable in the supernatants of

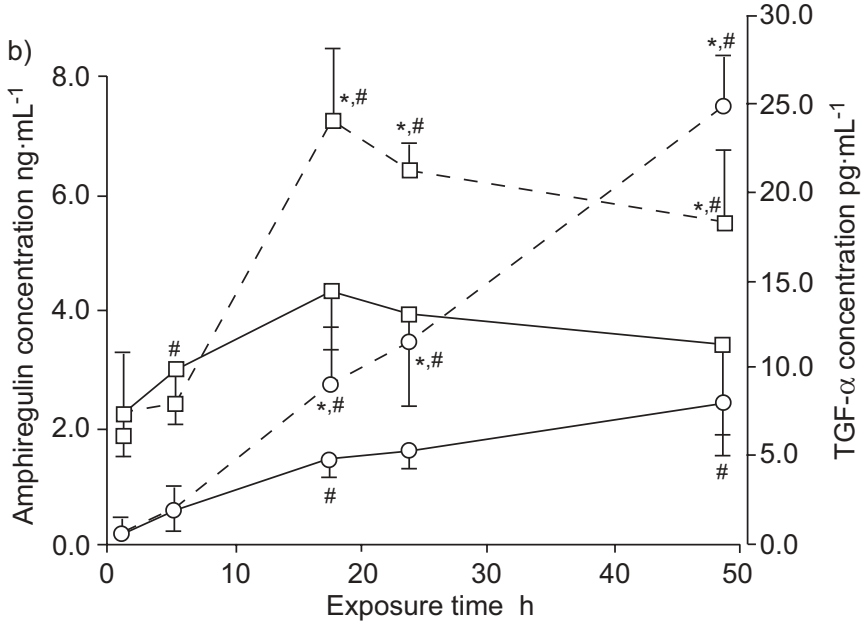

FIGURE 1. Epidermal growth factor receptor ligand expression in respiratory cells exposed to native particulate matter with a diameter below $2.5 \mu \mathrm{m}$ (PM2.5). a) Amphiregulin (O), betacellulin $(\square)$, heparin-binding epidermal growth factor-like growth factor $(\bullet)$ and transforming growth factor (TGF)- $\alpha(\square)$ mRNA expression in human bronchial epithelial (16HBE) cells exposed for $2-48 \mathrm{~h}$ to $10 \mu \mathrm{g} \cdot \mathrm{cm}^{-2}$ of PM2.5, measured by quantitative PCR. Relative abundance was obtained by the $2^{-\Delta \Delta C t}$ method. Reduced glyceraldehyde phosphate dehydrogenase (GAPDH) was used as internal control and the mRNA expression of PM2.5-treated cells was related to that of PM2.5 control. b) Amphiregulin ( $\bigcirc)$ and TGF- $\alpha(\square)$ release by 16HBE cells exposed for $2-48 \mathrm{~h}$ to $10 \mu \mathrm{g} \cdot \mathrm{cm}^{-2}$ of PM2.5 (-- $)$ or its control (-). c) Amphiregulin and d) TGF- $\alpha$ release by $16 \mathrm{HBE}$ cells and normal human nasal epithelial (NHNE) cells exposed to $10 \mu \mathrm{g} \cdot \mathrm{cm}^{-2}$ of PM2.5 ( $\square$ ) or its control ( $\square$ ) over a 24-h period and related to $16 \mathrm{HBE}$ or NHNE cell number. Data are expressed as mean $\pm \mathrm{SD}, \mathrm{n}=4$ (mRNA) or $\mathrm{n}=6$ (protein secretions). *: $\mathrm{p}<0.05$, significantly different from PM2.5 control; $\#$ : $p<0.05$, significantly different from the preceding period of exposure; ${ }^{\uparrow}$ : 2.4-fold increase; ${ }^{+}$: 1.4-fold increase; ${ }^{\text {s: }}$. 1.3-fold increase.

cells either at the basal level or after particle exposure (data not shown).

The comparison of EGFR ligand secretion induced by $10 \mu \mathrm{g} \cdot \mathrm{cm}^{-2}$ of PM2.5 in 16HBE cells and in primary cultures of epithelial cells (fig. 1c) revealed that amphiregulin and TGF$\alpha$ secretion was also induced by PM2.5-treated NHNE cells. In addition, when relating secretion data to cell number, figure $1 \mathrm{c}$ revealed that the amphiregulin concentration was six-fold higher in NHNE than in 16HBE supernatants. TGF- $\alpha$ was also more strongly secreted by NHNE cells than $16 \mathrm{HBE}$ cells, but to a higher extent (16-fold). Again, betacellulin secretion was not detectable (data not shown).

\section{Involvement of PM components in PM2.5-induced EGFR ligand upregulation}

Amphiregulin and TGF- $\alpha$ mRNA expression were measured by quantitative PCR after the treatment of $16 \mathrm{HBE}$ cells by noncytotoxic concentrations (data not shown) of PM2.5 organic and aqueous extracts. PM2.5 organic extract induced both amphiregulin and TGF- $\alpha$ mRNA expression (fig. $2 a$ and b), to approximately the same extent as native PM over $24 \mathrm{~h}$ of exposure, but with a sustained upregulation up to $48 \mathrm{~h}$ of treatment. In contrast, PM2.5 aqueous extract has only a very 

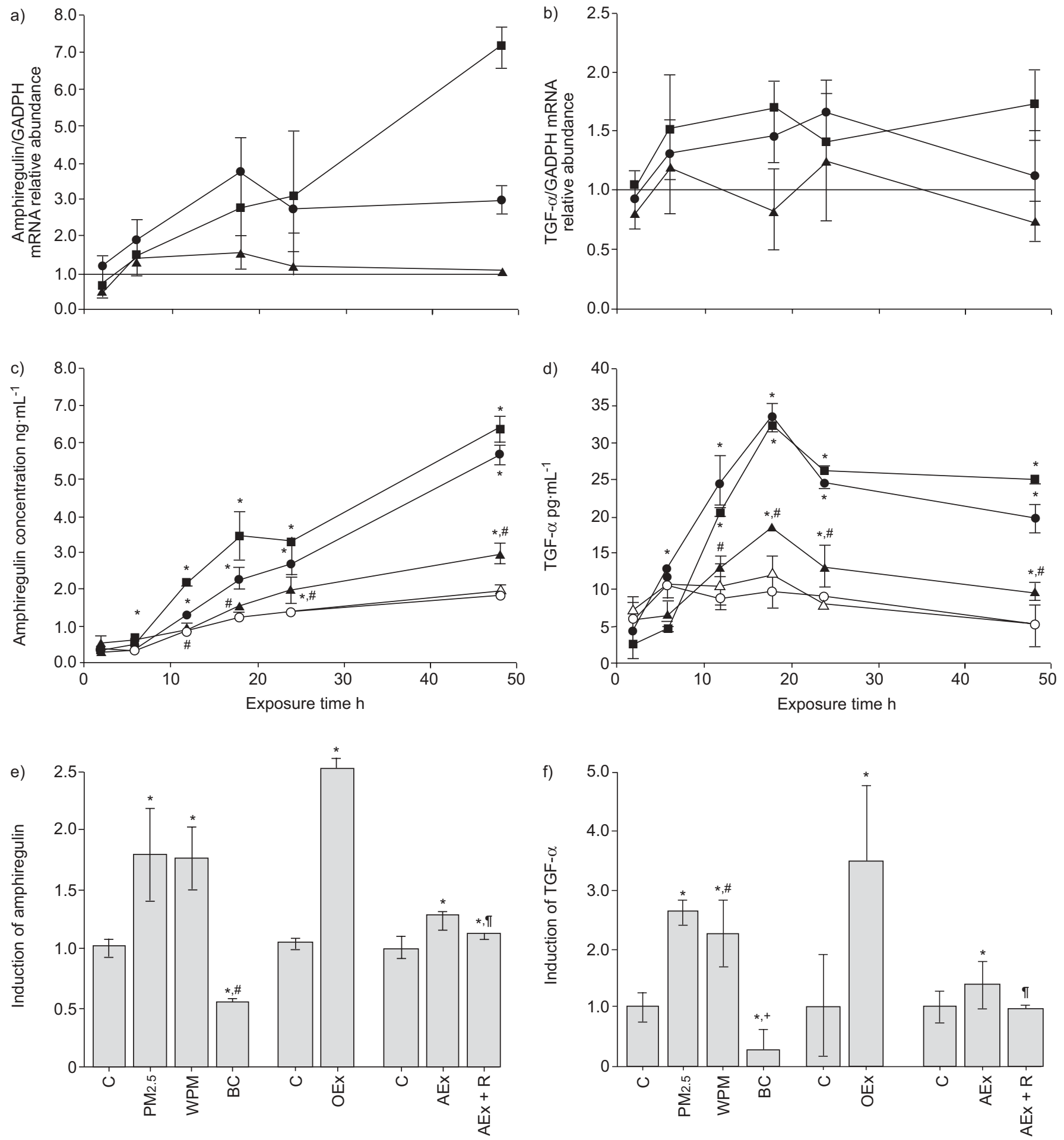

FIGURE 2. Contribution of particulate matter (PM) with a diameter below $2.5 \mu \mathrm{m}$ (PM2.5) components to epidermal growth factor receptor (EGFR) ligand upregulation. a) Amphiregulin and b) transforming growth factor (TGF)- $\alpha$ relative abundances compared with mRNA expression of reduced glyceraldehyde phosphate dehydrogenase (GAPDH) in human bronchial epithelial (16HBE) cells exposed to $10 \mu \mathrm{g} \cdot \mathrm{cm}^{-2}$ of PM2.5 ( $)$, or to an equivalent concentration of PM organic extract (OEx; $4.27 \mu \mathrm{g} \cdot \mathrm{mL}^{-1}$, $\left.\mathbf{a}\right)$ or to an equivalent volume of PM aqueous extract (AEx; $19 \mu \mathrm{L}, \mathbf{\Lambda}$ ) from 2-48 h of exposure. c) Amphiregulin and d) TGF- $\alpha$ release by $16 \mathrm{HBE}$ cells exposed from 2-48 $\mathrm{h}$. $\triangle$ : particle control; - PM2.5; $\mathbf{\square}$ : OEx; O: OEx control; $\mathbf{\Lambda}$ : AEx. e) Amphiregulin and f) TGF- $\alpha$ release induction by $16 \mathrm{HBE}$ cells exposed for $18 \mathrm{~h}$ to $10 \mu \mathrm{g} \cdot \mathrm{cm}^{-2}$ of PM with a diameter $<2.5 \mu \mathrm{m}(\mathrm{PM} 2.5)$, or to the equivalent volume of PM AEx (19 $\mu \mathrm{L})$ alone or with pre-treatment by a Chelex resin $(\mathrm{R})$, washed PM2.5 $\left(\mathrm{WPM} ; 10 \mu \mathrm{g} \cdot \mathrm{cm}^{-2}\right)$, black carbon $\left(\mathrm{BC} ; 10 \mu \mathrm{g} \cdot \mathrm{cm}^{-2}\right)$ and their relative control $(\mathrm{C})$ or to the equivalent concentration of PM OEx $\left(4.27 \mu \mathrm{g} \cdot \mathrm{mL}^{-1}\right)$ and its control. Data are expressed as mean $\pm \mathrm{SD}, \mathrm{n}=3$. ${ }^{*}$ : $\mathrm{p}<0.05$, significantly different from treatment control; \#: $p<0.05$, significantly different from PM2.5 treatment; ${ }^{\circ}: p<0.05$, significantly different from AEx treatment. 

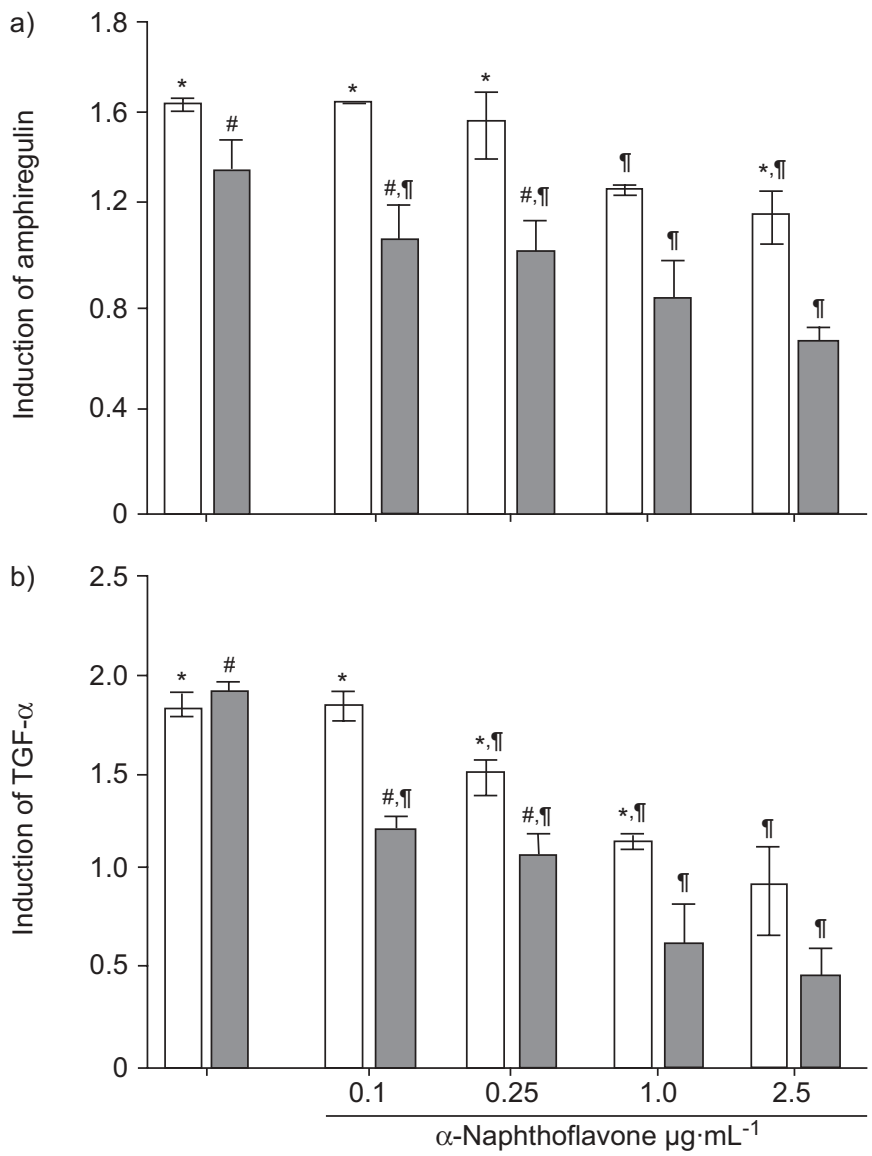

FIGURE 3. Involvement of the aryl hydrocarbon receptor (AhR) pathway in particulate matter (PM)-induced epidermal growth factor receptor ligand secretion. a) Amphiregulin and b) transforming growth factor (TGF)- $\alpha$ release induction by human bronchial epithelial cells exposed for $24 \mathrm{~h}$ to $10 \mu \mathrm{g} \cdot \mathrm{cm}^{-2}$ of PM with a diameter below $2.5 \mu \mathrm{m}$ (PM2.5: $\square$ ) or $1 \mu \mathrm{M}$ of benzo(a)pyrene ( $\square$ ) alone or with 30 min pre-treatment by $0.1-2.5 \mu \mathrm{g} \cdot \mathrm{mL}^{-1}$ of $\alpha$-naphthoflavone, an AhR antagonist. Data are expressed as mean $\pm S D, n=3$. *: $p<0.05$, significantly different from $P M 2.5$ control; ${ }^{*}$ : $p<0.05$, significantly different from benzo(a)pyrene control; ${ }^{\top}: p<0.05$, significantly different from release without pre-treatment by $\alpha$-naphthoflavone.

transient and weak effect on amphiregulin mRNA expression (fig. 2a) and no significant effect on TGF- $\alpha$ mRNA expression (fig. 2b).

A kinetic study (fig. $2 c$ and d) revealed that amphiregulin and TGF- $\alpha$ release was significantly induced by the organic PM extract from $6 \mathrm{~h}$ of exposure, with a level of induction almost similar to the one of native PM. The aqueous extract also induced amphiregulin and TGF- $\alpha$ release with a significant induction from 18-24 h of exposure (fig. 2c and d). The level of induction was far weaker than that of native PM (fig. $2 \mathrm{c}-\mathrm{f}$ ) and was almost completely abrogated when metals were removed from the aqueous extract using a Chelex resin (fig. 2e and f).

Washed particles, devoid of their hydrosoluble compounds, induced amphiregulin and TGF- $\alpha$ to approximately the same level as native PM2.5 (1.8- and 2.5-fold for amphiregulin and TGF- $\alpha$, respectively; fig. 2e and f), while there was virtually no effect of black carbon on amphiregulin and TGF- $\alpha$ release (fig. 2e and f). NHNE cells responded in a similar fashion to

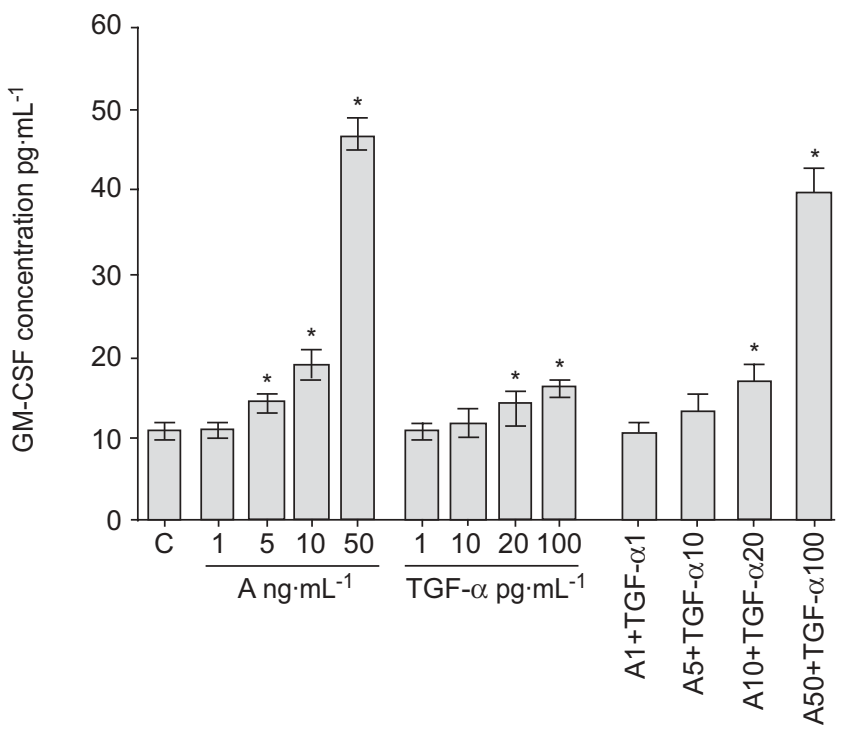

FIGURE 4. Pro-inflammatory response triggered in bronchial epithelial cells exposed to epidermal growth factor receptor (EGFR) ligands. Granulocytemacrophage colony-stimulating factor (GM-CSF) release by human bronchia epithelial cells exposed for $24 \mathrm{~h}$ to $1-50 \mathrm{ng} \cdot \mathrm{mL}^{-1}$ of amphiregulin (A), $1-100 \mathrm{pg} \cdot \mathrm{mL}^{-1}$ of transforming growth factor (TGF)- $\alpha$ or to the combination of these two EGFR ligands. Data are expressed as mean $\pm S D, n=3$. C: control. *: $p<0.05$, significantly different from control.

$16 \mathrm{HBE}$ cells (fig. 2, supplementary online material) except for a slight increase or absence of response in TGF- $\alpha$ release by NHNE cells treated by PM organic and aqueous extracts (1.8and 1.7-fold, respectively).

Since PM organic extract had the greatest effect on EGFR ligand expression and $\mathrm{PAH}$ represent constituents of this extract, the effect of PM2.5-induced EGFR ligand secretion as mediated by the AhR pathway, was investigated. Figure 3 demonstrates that both amphiregulin and TGF- $\alpha$ release provoked by $10 \mu \mathrm{g} \cdot \mathrm{cm}^{-2}$ of PM2.5 diminished with the addition of $\alpha$-naphthoflavone, an AhR antagonist, in a concentrationdependent manner. Furthermore, $\alpha$-naphthoflavone decreased the amphiregulin and TGF- $\alpha$ secretion induced by $1 \mu \mathrm{M}$ of benzo(a)pyrene (used as positive control) more than the secretion induced by PM2.5.

\section{EGFR ligands mediate a PM2.5-induced epithelial cell autocrine pro-inflammatory response}

When 16HBE cells were exposed for $24 \mathrm{~h}$ to human recombinant amphiregulin or TGF- $\alpha$ (fig. 4), the GM-CSF pro-inflammatory cytokine secretion was induced by an exposure to $5 \mathrm{ng} \cdot \mathrm{mL}^{-1}$ of amphiregulin or $20 \mathrm{pg} \cdot \mathrm{mL}^{-1}$ of TGF- $\alpha$. Cotreatment with both amphiregulin and TGF- $\alpha$ had no additive effect on GM-CSF release (fig. 4).

In order to determine whether GM-CSF release, known to be induced by PM2.5 [12], was regulated in an autocrine manner by EGFR ligands, conditioned media of cells previously exposed to PM2.5 for $24 \mathrm{~h}$ was used (fig. 5). Figure 5a demonstrates that a $24 \mathrm{~h}$ exposure to $10 \mu \mathrm{g} \cdot \mathrm{cm}^{-2}$ of PM2.5 induced GM-CSF secretion (increase of $35 \mathrm{pg} \cdot \mathrm{mL}^{-1}$ in treated cells versus control cells, fig. 5a). The transfer of the conditioned 

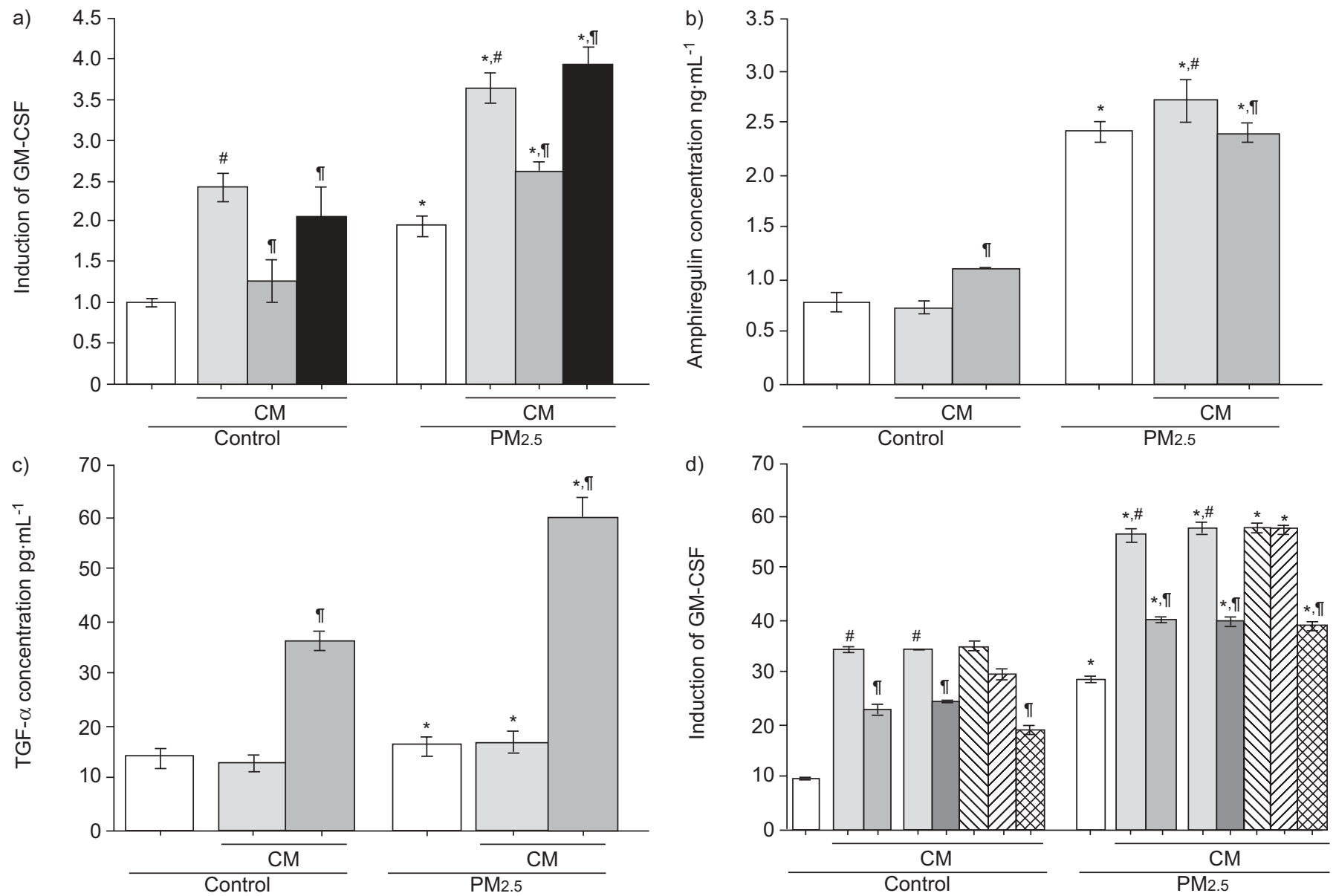

FIGURE 5. Pro-inflammatory response of bronchial epithelial cells exposed to particulate matter (PM) or conditioned media (CM). a and d) granulocyte-macrophage colony-stimulating factor (GM-CSF) release induction, b) amphiregulin or c) transforming growth factor (TGF)- $\alpha$ release by human bronchial epithelial (16HBE) cells exposed directly to $10 \mu \mathrm{g} \cdot \mathrm{cm}^{-2}$ of PM with a diameter below $2.5 \mu \mathrm{m}$ (PM2.5) or PM2.5 control for $24 \mathrm{~h}(\square)$. Fresh cells were then exposed to either control- or PM2.5-CM alone ( $\square$ ) or CM following: $0.5 \mu \mathrm{g} \cdot \mathrm{mL}^{-1}$ anti-epidermal growth factor (EGF) receptor antibody treatment ( $\square$ ); treatment with $0.5 \mu \mathrm{g} \cdot \mathrm{mL}^{-1}$ of immunoglobulin $\mathrm{G}$ antibody ( $\square$ ); pre-treatment with

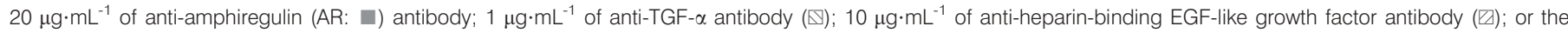
combination of anti-heparin-binding EGF-like growth factor, anti-AR and anti-TGF- $\alpha$ antibodies (㯰). GM-CSF induction is normalised by the cells directly exposed to control. Data are expressed as mean $\pm \mathrm{SD}, \mathrm{n}=6$ or $\mathrm{n}=3$. ${ }^{*}: \mathrm{p}<0.05$, significantly different from treatment control; ${ }^{*}: \mathrm{p}<0.05$, significantly different from release by cells directly exposed to $\mathrm{PM} 2.5 ;{ }^{\circ}: \mathrm{p}<0.05$, significantly different from release by cells exposed to $\mathrm{CM}$.

media onto fresh cells further increased GM-CSF secretion by cells exposed to either control conditioned media or to PM2.5 conditioned media, but the increase in GM-CSF secretion was greater in cells exposed to PM2.5 conditioned media (increase of $46 \mathrm{pg} \cdot \mathrm{mL}^{-1}$ in PM2.5-conditioned media versus control conditioned media; fig. 5a). Interestingly, when conditioned media was applied to fresh cells in addition to $0.5 \mu \mathrm{g} \cdot \mathrm{mL}^{-1}$ of an anti-EGFR antibody (fig. $5 \mathrm{a}$ ), the conditioned media-induced GM-CSF release was strongly reduced both for control and PM2.5-conditioned media, in contrast to the addition of $0.5 \mu \mathrm{g} \cdot \mathrm{mL}^{-1}$ of control ( $\left.\mathrm{IgG}\right)$ antibody, which had almost no effect on GM-CSF release (fig. 5a). Furthermore, the GM-CSF secretion induced by conditioned media was concentration dependent, occurring from conditioned media of cells exposed to $1 \mu \mathrm{g} \cdot \mathrm{cm}^{-2}$ of PM2.5 (fig. 3 in the online supplementary material). The measurements of amphiregulin and TGF- $\alpha$ release in parallel to GM-CSF release (fig. $5 b$ and c) revealed that: 1) secretion levels of these two ligands were increased only slightly or not at all by fresh cells exposed for $24 \mathrm{~h}$ to conditioned media; and 2) the addition of an anti-EGFR antibody only slightly modulated secretion levels of amphiregulin, whereas a strong increase in TGF- $\alpha$ release was observed, especially in PM-treated cultures.

In order to determine the respective roles of the different EGFR ligands in GM-CSF release, antibodies against amphiregulin, TGF- $\alpha$ or HB-EGF were used either alone or in combination in conditioned media (fig. 5d). Only the anti-amphiregulin antibody alone or in combination with the other antibodies significantly reduced the GM-CSF secretion, to the same extent as the anti-EGFR antibody (fig. 5d).

\section{DISCUSSION}

PM2.5 upregulates several EGFR ligands in respiratory epithelial cells

The current study demonstrates for the first time that urban PM2.5 differentially regulates by respiratory epithelial cell 
mRNA expression of EGFR ligands, with upregulation of TGF- $\alpha$, amphiregulin and HB-EGF but unchanged betacellulin expression. The three induced growth factors have similar gene expression kinetics, but different levels of induction. These differences also occur with protein release, since amphiregulin exhibits higher expression both at the mRNA and protein level (3.6- and 2-3.5-fold, respectively) than TGF- $\alpha$ (2.1- and 1.4-1.7-fold for mRNA and protein, respectively). These data suggest that increased EGFR ligand secretion results from increased gene expression. To the current authors' knowledge, this effect of PM on EGFR ligand secretion by respiratory epithelial cells has not been published previously. However, TGF- $\alpha$, amphiregulin and HB-EGF gene upregulation has already been shown in the lung epithelial cell line (NCI-H292) exposed to cigarette smoke, where amphiregulin secretion was stronger than that of TGF- $\alpha$ [11]. Similarly, the present protein release kinetic study revealed that TGF- $\alpha$ induction is weaker than that of amphiregulin and does not accumulate in the cell medium. This weaker induction may be misleading, as underlined by the experiment performed in the presence of an anti-EGFR antibody, which blocks binding of TGF- $\alpha$ to EGFR, leading to a dramatic increase in TGF- $\alpha$ in the culture medium (fig. $5 \mathrm{c}$ ). This suggests that TGF- $\alpha$ is quickly consumed by cells due to its strong affinity for EGFR. Moreover, this would explain the picogram amounts of TGF$\alpha$ that were measured in vitro as well as those obtained in airway epithelial cells exposed to cigarette smoke [14].

EGFR ligand secretion may be a common response of respiratory epithelial cells to stress, as underlined by miscellaneous data obtained with human bronchial epithelial cells exposed to cigarette smoke [11] or after inhalation of asbestos fibres by rats [15]. These data, combined with the present study, performed with a bronchial cell line and nasal primary cells, underline the fact that induced release of EGFR ligands is not limited to cell lines and occurs throughout the respiratory tract: nasal and bronchial cells responding in a similar fashion. Furthermore, amphiregulin [16] and TGF- $\alpha$ [17] have been described as being preferentially released towards the basolateral compartment, while EGFR is localised in the basolateral membrane [13], which suggests that PM2.5-induced EGFR ligands could mediate responses of bronchial epithelial cells via an autocrine effect.

\section{PM2.5-induced EGFR ligands mediate a pro-inflammatory response of bronchial epithelial cells but not their proliferation}

Airway inflammation is the most frequently described and most well-known effect of short-term exposure of healthy volunteers to PM and diesel exhaust particulate (DEP) [18, 19], and can be explained by the capacity of these particles to induce the release of pro-inflammatory cytokines such as IL-8, TNF- $\alpha$ and GM-CSF $[4,16]$. Mechanistic studies performed to elucidate signalling pathways triggered by PM in order to induce cytokine release have underlined the involvement of EGFR activation [7, 20]. Such EGFR activation could be a direct effect of particles, as shown for asbestos [21], but it is tempting to hypothesise that the PM2.5-induced epithelial cell proinflammatory response could be mediated and/or amplified via EGFR activation by PM2.5-induced EGFR ligands. This assumption was assessed using conditioned media in the presence or absence of an antibody to block the binding of EGFR ligands to their receptor. These data highlight the maintenance of GM-CSF release by cells, particularly when exposed to PM, and the strong participation of EGFR ligands in constitutive and PM-enhanced GM-CSF sustained release. Amphiregulin and TGF- $\alpha$ may be specifically involved in this response, as both ligands appeared to induce GM-CSF secretion by cells when used at concentrations found in PM2.5-treated cells (fig. 4), and to be entirely consumed by $16 \mathrm{HBE}$ cells exposed to conditioned media, as shown in figure $5 b$ and c. Nevertheless, the use of antibodies directed towards the different EGFR ligands suggest that GM-CSF secretion is mainly driven by amphiregulin. These results suggest that PM2.5 could exacerbate and sustain bronchial epithelial cell inflammation. The autocrine effects of EGFR ligands may thus be a parameter explaining exacerbation of asthma by PM [22], since asthmatic subjects exhibit overexpression of EGFR in bronchial epithelium [10].

Beside the regulation of a pro-inflammatory response in epithelial cells, the current authors speculated whether EGFR ligands secreted after PM2.5 treatment could also mediate a mitogen effect on bronchial epithelial cells, since EGFR ligands are known to exhibit growth factor properties. Nevertheless, the culture of bronchial epithelial cells with conditioned media of PM-treated cells did not reveal any modification of cell proliferation (data not shown).

\section{PM2.5 organic components mainly contribute to amphiregulin and TGF- $\alpha$ upregulation}

Fractionation of PM2.5 reveals that PM aqueous extract induces weak but significant amphiregulin and TGF- $\alpha$ release by $16 \mathrm{HBE}$ cells that is abolished when metals are trapped by a Chelex resin, suggesting a main contribution of metals to growth factor induction by PM aqueous components. These results, already reported for amphiregulin [23], corroborate findings linking pro-inflammatory cytokine production by epithelial cells to the metal content of PM [24]. The present study sheds new light on the contribution of organic particle compounds to PM2.5-induced amphiregulin and TGF- $\alpha$ gene expression and protein secretion. Indeed, extracted organic PM components, as well as water-washed PM2.5 still bearing its organic content, both appear to induce amphiregulin and TGF$\alpha$ secretion, whereas inorganic carbonaceous compounds have no effect on such growth factor release (fig. $2 \mathrm{e}$ and $\mathrm{f}$ and supplementary fig. 2). This strong involvement of organic components in PM2.5-induced EGFR ligand expression has already been shown for amphiregulin [13, 23].

The organic component of PM2.5 contains PAH, known to have biological activities, especially through specific binding to the AhR. $\alpha$-naphthoflavone, an AhR antagonist, diminished PMinduced secretion of amphiregulin and TGF- $\alpha$ (fig. 3), suggesting AhR-dependent transcriptional regulation of amphiregulin and TGF- $\alpha$, which has already been described for another EGFR ligand, epiregulin, in 2,3,7,8-tetrachlorodibenzo-pdioxin-treated mouse cells [25]. This hypothesis is reinforced by the identification of consensus xenobiotic responsive element sequences upstream of the transcriptional start site in human amphiregulin and TGF- $\alpha$ promoters, to which a transcriptional complex including $\mathrm{PAH}$ and $\mathrm{AhR}$ binds to transactivate genes. But the presence of cyclic adenosine 
monophosphate (CAMP) responsive element (CRE) sequences in amphiregulin and TGF- $\alpha$ promoters could also explain this AhR-dependent signalling pathway; indeed, Du et al. [26] recently described induced amphiregulin expression triggered by cigarette smoke in bronchial cells that involves an AhR $\rightarrow$ $\mathrm{cAMP} \rightarrow \mathrm{PKA} \rightarrow \mathrm{CRE}$ pathway. An additional regulation pathway could be linked to the ability of PM components to induce oxidative stress. This pathway could activate the oxidative stress-sensitive transcription factor, nuclear factor$\kappa \mathrm{B}$, previously shown to be activated in DEP- and PM2.5exposed epithelial cells [27, 28], and present consensus binding sites in amphiregulin and TGF- $\alpha$ promoters.

In conclusion, the current study reports upregulation of several epidermal growth factor receptor ligands by human airway epithelial cells exposed to urban particulate matter with a diameter $<2.5 \mu \mathrm{m}$, and in particular, the strong participation of organic components of particulate matter with a diameter $<2.5 \mu \mathrm{m}$ in amphiregulin and transforming growth factor- $\alpha$ upregulation and the weaker contribution of aqueous components through mechanisms that require further investigation. The current study demonstrates for the first time that particulate matter with a diameter $<2.5 \mu \mathrm{m}$ induced amphiregulin and transforming growth factor- $\alpha$ release contribute to the bronchial pro-inflammatory response via an autocrine action. Amplification of bronchial inflammation is highly suspected to be responsible for bronchial remodelling, notably found in asthma or chronic obstructive pulmonary disease. The present findings may thus have clinical implications, especially since amphiregulin and transforming growth factor$\alpha$ appear significantly released after exposure to only $1 \mu \mathrm{g} \cdot \mathrm{cm}^{-2}$ of native particulate matter with a diameter $<2.5 \mu \mathrm{m}$, a concentration easily reached in the tracheobronchial region of individuals with respiratory diseases living in polluted urban areas [22]. In addition to the role of particulate matter-induced epidermal growth factor receptor ligands in sustained bronchial inflammation, they may also have paracrine effects on other cellular actors involved in airway remodelling, such as fibroblasts or vascular smooth muscle cells previously described to be sensitive to such ligands $[29,30]$.

\section{ACKNOWLEDGEMENTS}

The authors would like to acknowledge the technical assistance of A. Jaeger (Laboratory of Cytophysiology and Cellular Toxicology, University of Paris Diderot, Paris, France), J. Bram for English editing and S. Middendorp (Laboratory of Regulation of Immune Responses, University of Paris 7, Paris, France) for precious help in gene promoter analysis.

\section{REFERENCES}

1 Brunekreef B, Holgate ST. Air pollution and health. Lancet 2002; 360: 1233-1242.

2 Diaz-Sanchez D, Tsien A, Fleming J, Saxon A. Combined diesel exhaust particulate and ragweed allergen challenge markedly enhances human in vivo nasal ragweed-specific $\mathrm{IgE}$ and skews cytokine production to a T helper cell 2-type pattern. J Immunol 1997; 158: 2406-2413.

3 Ghio AJ, Huang YC. Exposure to concentrated ambient particles (CAPs): a review. Inhal Toxicol 2004; 16: 53-59.
4 Baulig A, Sourdeval M, Meyer M, Marano F, BaezaSquiban A. Biological effects of atmospheric particles on human bronchial epithelial cells. Comparison with diesel exhaust particles. Toxicol In Vitro 2003; 17: 567-573.

5 Churg A, Brauer M, del Carmen Avila-Casado M, Fortoul TI, Wright JL. Chronic exposure to high levels of particulate air pollution and small airway remodeling. Environ Health Perspect 2003; 111: 714-718.

6 Benayoun L, Pretolani M. [Airway remodeling in asthma: mechanisms and therapeutic perspectives]. Med Sci (Paris) 2003; 19: 319-326.

7 Blanchet S, Ramgolam K, Baulig A, Marano F, BaezaSquiban A. Fine particulate matter induces amphiregulin secretion by bronchial epithelial cells. Am J Respir Cell Mol Biol 2004; 30: 421-427.

8 Tsao MS, Zhu H, Viallet J. Autocrine growth loop of the epidermal growth factor receptor in normal and immortalized human bronchial epithelial cells. Exp Cell Res 1996; 223: 268-273.

9 Bonner JC. The epidermal growth factor receptor at the crossroads of airway remodeling. Am J Physiol Lung Cell Mol Physiol 2002; 283: L528-L530.

10 Puddicombe SM, Polosa R, Richter A, et al. Involvement of the epidermal growth factor receptor in epithelial repair in asthma. FASEB J 2000; 14: 1362-1374.

11 Richter A, O'Donnell RA, Powell RM, et al. Autocrine ligands for the epidermal growth factor receptor mediate interleukin-8 release from bronchial epithelial cells in response to cigarette smoke. Am J Respir Cell Mol Biol 2002; 27: 85-90.

12 Baulig A, Poirault JJ, Ausset P, et al. Physicochemical characteristics and biological activities of seasonal atmospheric particulate matter sampling in two locations of Paris. Environ Sci Technol 2004; 38: 5985-5992.

13 Rumelhard M, Ramgolam K, Auger F, et al. Effects of PM2.5 components in the release of amphiregulin by human airway epithelial cells. Toxicol Lett 2007; 168: 155-164.

14 Shao MX, Nakanaga T, Nadel JA. Cigarette smoke induces MUC5AC mucin overproduction via tumour necrosis factor- $\alpha$-converting enzyme in human airway epithelial (NCI-H292) cells. Am J Physiol Lung Cell Mol Physiol 2004; 287: L420-L427.

15 Liu JY, Morris GF, Lei WH, Corti M, Brody AR. Upregulated expression of transforming growth factor- $\alpha$ in the bronchiolar-alveolar duct regions of asbestos-exposed rats. Am J Pathol 1996; 149: 205-217.

16 Auger F, Gendron MC, Chamot C, Marano F, Dazy AC. Responses of well-differentiated nasal epithelial cells exposed to particles: role of the epithelium in airway inflammation. Toxicol Appl Pharmacol 2006; 215: 285-294.

17 Harris RC, Chung E, Coffey RJ. EGF receptor ligands. Exp Cell Res 2003; 284: 2-13.

18 Salvi S, Blomberg A, Rudell B, et al. Acute inflammatory responses in the airways and peripheral blood after shortterm exposure to diesel exhaust in healthy human volunteers. Am J Respir Crit Care Med 1999; 159: 702-709.

19 Li XY, Gilmour PS, Donaldson K, MacNee W. In vivo and in vitro proinflammatory effects of particulate air pollution (PM10). Environ Health Perspect 1997; 105: Suppl. 5, 1279-1283.

$20 \mathrm{Wu}$ W, Samet JM, Ghio AJ, Devlin RB. Activation of the EGF receptor signaling pathway in airway epithelial cells 
exposed to Utah Valley PM. Am I Physiol Lung Cell Mol Physiol 2001; 281: L483-L489.

21 Zanella CL, Timblin CR, Cummins A, et al. Asbestosinduced phosphorylation of epidermal growth factor receptor is linked to c-fos and apoptosis. Am J Physiol 1999; 277: L684-L693.

22 Li N, Hao M, Phalen RF, Hinds WC, Nel AE. Particulate air pollutants and asthma. A paradigm for the role of oxidative stress in PM-induced adverse health effects. Clin Immunol 2003; 109: 250-265.

23 Baulig A, Blanchet S, Rumelhard M, Lacroix G, Marano F, Baeza-Squiban A. Fine urban atmospheric particulate matter modulates inflammatory gene and protein expression in human bronchial epithelial cells. Front Biosci 2007; 12: 771-782.

24 Saldiva PH, Clarke RW, Coull BA, et al. Lung inflammation induced by concentrated ambient air particles is related to particle composition. Am J Respir Crit Care Med 2002; 165: 1610-1617.

25 Patel RD, Kim DJ, Peters JM, Perdew GH. The aryl hydrocarbon receptor directly regulates expression of the potent mitogen epiregulin. Toxicol Sci 2006; 89: 75-82.
26 Du B, Altorki NK, Kopelovich L, Subbaramaiah K, Dannenberg AJ. Tobacco smoke stimulates the transcription of amphiregulin in human oral epithelial cells: evidence of a cyclic AMP-responsive element binding protein-dependent mechanism. Cancer Res 2005; 65: 5982-5988.

27 Bonvallot V, Baeza-Squiban A, Baulig A, et al. Organic compounds from diesel exhaust particles elicit a proinflammatory response in human airway epithelial cells and induce cytochrome p450 1A1 expression. Am J Respir Cell Mol Biol 2001; 25: 515-521.

28 Nel AE, Diaz-Sanchez D, Li N. The role of particulate pollutants in pulmonary inflammation and asthma: evidence for the involvement of organic chemicals and oxidative stress. Curr Opin Pulm Med 2001; 7: 20-26.

29 Zhang L, Rice AB, Adler $\mathrm{K}$, et al. Vanadium stimulates human bronchial epithelial cells to produce heparinbinding epidermal growth factor-like growth factor: a mitogen for lung fibroblasts. Am J Respir Cell Mol Biol 2001; 24: 123-131.

30 Kato M, Inazu T, Kawai Y, et al. Amphiregulin is a potent mitogen for the vascular smooth muscle cell line, A7r5. Biochem Biophys Res Commun 2003; 301: 1109-1115. 